\title{
声門後部療着症の治療経験
}

\author{
米川紘子・玉木克彦・江 龍誠・竹山 豊 \\ 太王文彦

\section{Surgical Treatment of Posterior Glottic Stenosis : A Case Report}

\author{
Hiroko Yonekawa, Katsuhiko Tamaki, Makoto Eryu, \\ Yutaka Takeyama and Fumihiko Ohta
}

\begin{abstract}
A 42-year-old man developed posterior glottic stenosis following an attempt of self-burning. He was intubated for 2 weeks and tracheotomy was performed for a failure of extubation. Laryngoscopy revealed adhesion at the posterior glottis which severely limited abduction of both vocal folds and arytenoids. The scar tissue of the posterior glottis was resected by means of carbon dioxide laser under endolaryngeal microsurgery on two occasions. These two procedure, however, were not successful to stop recurrent stenosis.

An open surgery was conducted. Following laryngofissure, scar tissues were submucously removed. The wound at the posterior glottis was covered by rotation mucosal flaps obtained from the postcricoid area and a free buccal mucosa graft. Human fibrin glue was employed for the grafting. The posterior glottic space was sufficiently enlarged. The tracheostoma was closed 10 months after the surgery. Two years and 6 months after the surgery, the patient has a good respiratory and phonatory function.

On the basis of the successful result in the present case, the authors emphasize the usefulness of free mucosal graft with fibrin glue in the treatment of posterior glottic stenosis. This procedure does not call for the use of a laryngeal stent.
\end{abstract}

Key words : posterior glottic stenosis, laryngofissure, free mucosal flap, fibrin glue

\section{はじめに}

声門狭窄の治療の原則は音声機能を温存して呼吸機能を 改善することであるが，病態によっては治療が困難で厄介 な問題を残す場合がある.われわれは，気道熱傷を負った 直後に気管内挿管を受け声門後部に瘾着を生じた症例に対 して, 喉頭截開下にフィブリン糊を利用して粘膜移植を行 い良好な結果を得たので報告する。

\section{症例}

患者：42歳, 男性

主訴：労作時の呼吸困難

初診日：昭和 61 年 4 月 18 日

既往歴：特記すべきことなし

現病歴：昭和 61 年 3 月 4 日, 灯油で焼身自殺を謀り顔面, 両側大腿, 両側手背, 背部に全身のほぼ $40 \%$ にたる II III度の熱傷を負い, 救命センターで気管内挿管の処置を受 けて救命された．同時に行われた気管支ファイバースコピー では気管支内腔は煤で覆われており, 粘膜は発赤浮腫状で 気道熱傷と診断された．挿管チューブは 2 週間後に抜管さ
れたが，労作時の呼吸困難が出現したため当科を受診した. 間接喉頭鏡検査では喉頭に明かな炎症はなく, 声門間隙は 約 $3 \mathrm{~mm}$ で，両側披裂部の外転運動は著明に制限されてお り両側声帯麻痺と診断された。鼻粘膜は発赤著明, 口唇に は瘏痕拘縮が認められたが口腔，咽頭腔には特に異常は認 められなかった。会話音声はほぼ正常であった，5月28日， 同センターで気管切開術を受け，口唇と手背の植皮術のた め形成外科に入院したため当科を受診していない。気管切 開孔は 3 力月後に閉鎖されている. 昭和62年12月初めより， 労作時の息苦しさが増強してきたため昭和 63 年 5 月 6 日当 科に治療目的で入院した。

入院時の喉頭所見：喉頭ファイバースコープによる観察 では両側の声帯膜様部は正常であったが，声帯突起部より 後方は膜様に癒着し両側披裂部間には索状の㓔痕性瘾着を 認めた. 声帯と披裂部の外転運動は強く障害されており声 門後部癒着症と診断した. 声門間隙の大きさは図 1 に示す 程度で, 安静時の呼吸には支障はない。しかし，呼吸機能 検査では比肺活量 $89.6 \%, 1$ 秒量 $2.311,1$ 秒率 $62.6 \%$ ，フ ローボリューム曲線は最大呼気流率 $1.5 \mathrm{~L} / \mathrm{sec}$ でピークが 平坦化した明らかな上気道閉塞パターンを示した（図 $2-$ 


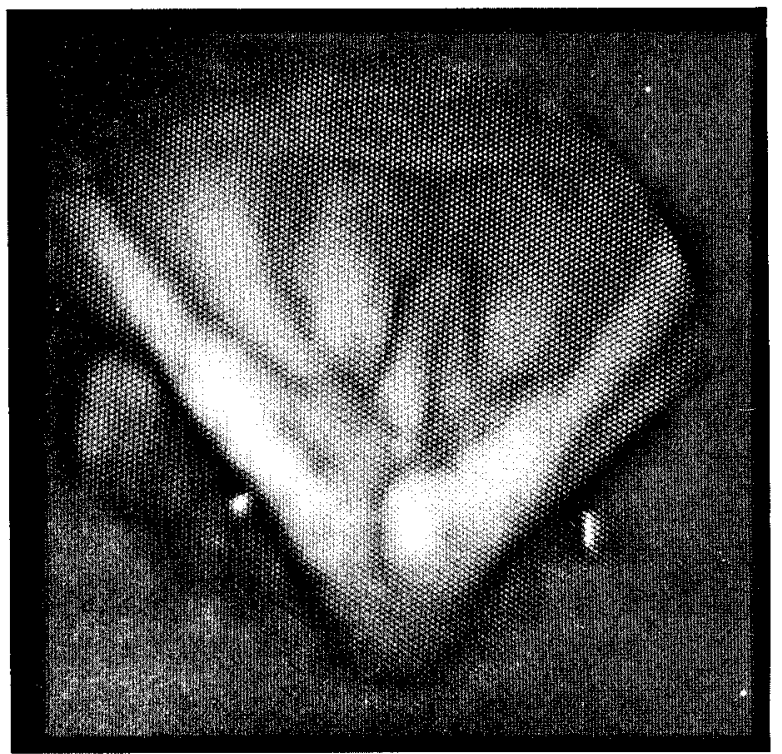

a

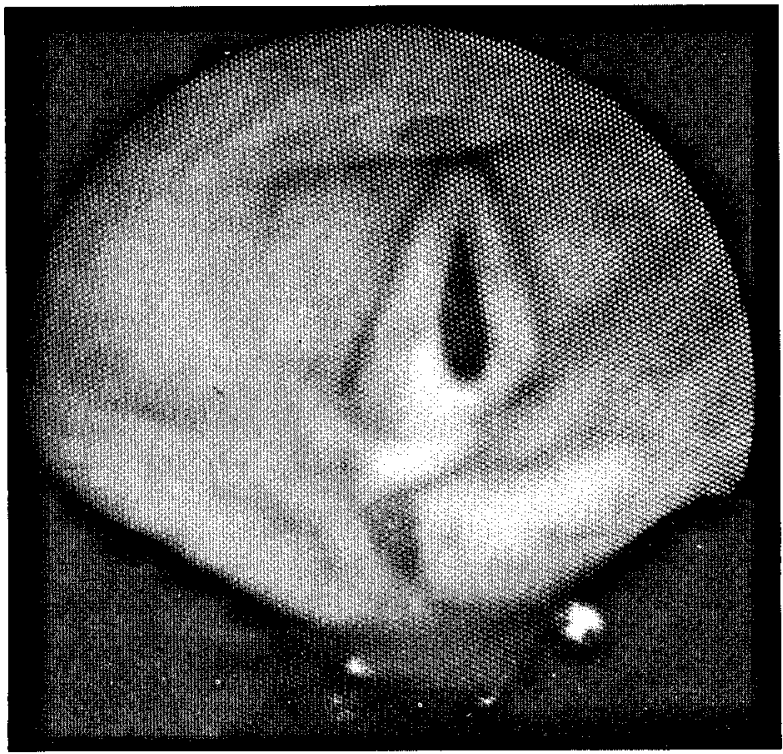

b

図 1 入院時の喉頭像 $a$ : 安静呼吸時 $b$ : 発声時 a). 音声機能検査は嗄声度：G 1 R 0.5 B 1 A 0 S 0.5 , MPT : $5 \mathrm{sec}, \mathrm{SH}-01$ (リオン) による発声機能検査では, 声の高さ : $127 \mathrm{~Hz}$, 音圧 : $88.7 \mathrm{~dB}$, 平均呼気流率 : $157 \mathrm{ml}$ /secであった.

治療経過：昭和63年 5 月 9 日, NLA 無挿管麻酔下に喉 頭マイクロレーザー手術を行い痖着部を蒸散して切り離し た. 2 力月後に同部が入院時とほほ同じ程度に痖着し声閒 が狭窄してきたため，8月 4 日，気管切開術を行い，気管 切開孔より挿管し GOF 全身麻䤃下に喉頭マイクロレーザー 手術を施行した。声門後壁は輪状軟骨板の上緑から䄪 1 $\mathrm{cm}$ 下方までと, 声带突起部の軟骨と披裂筋の一部が露出 するまで前回よりも広範囲に癞痕組織を蒸散し除去した。 声帯が内転した状態で声門後部に十分な間隙ができるよう に形態を整え，両側披裂部の可動性があることを確認した (図 3 )。再痻着防止のために, チューブ脚の吻側端が声門 上に出るように径 $12 \mathrm{~mm} の \mathrm{~T}$ チューブ（シリコン製）を 挿入した。しかし, 術後患者が不穏状態になり局所の安定 がとれず，その日のうちにチューブを抜去して気管カニュー レに替えざるを得なかった，術後の創傷治况の経過は順調 で，両側披裂部の内外転運動も安定し声門が開大したこと を確認して（図 4)，7 週間後に気管切開孔を閉鎖した。 しかし，再び徐々に声門後部が狭くなってきたので（図 5), 6 力月後（平成 1 年 1 月 29 日）に気管切開術と喉頭截開術 を施行した。

甲状軟骨を正中で切開し喉頭内腔を見ると両側声帯は声 帯軟骨部から声門後壁まで癜痕性に瘾着し棚状をなし, 療 着した披裂部間の頂上へ移行する形をとっていた（図6). 手術用顕微鏡下に療着した粘膜を輪軟状骨板の上 $1 / 3$ の高さまで切り離し, 粘膜を保存して粘膜下の瘕痕組織と 㓔痕化した披裂筋の一部を鉗除した。つぎに，披裂部後面

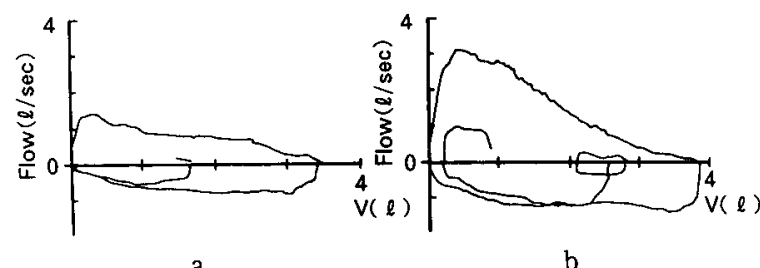

图 $2 \mathrm{FV}$ 曲線 $\mathrm{a}$ : 入院時 $\mathrm{b}$ ：喉頭截開術後 2 年 6 力月目

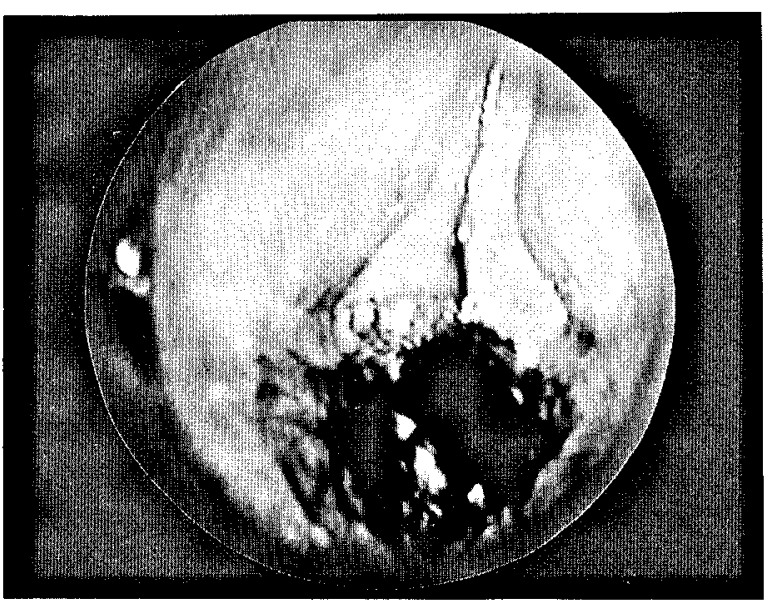

図 3 喉頭マイクロレーザー手術（2 回目）

の粘膜を移動して披裂部内側面の創部を覆い, 周囲粘膜と 縫合して左右の披裂部の隆起を形成した. 頓部粘膜を移植 粘膜弁 $(1.5 \times 2.0 \mathrm{~cm})$ として粘膜欠損部に吸収系で䋖合し， さらにフィブリン糊を移植床と移植粘膜弁の間に注入して 

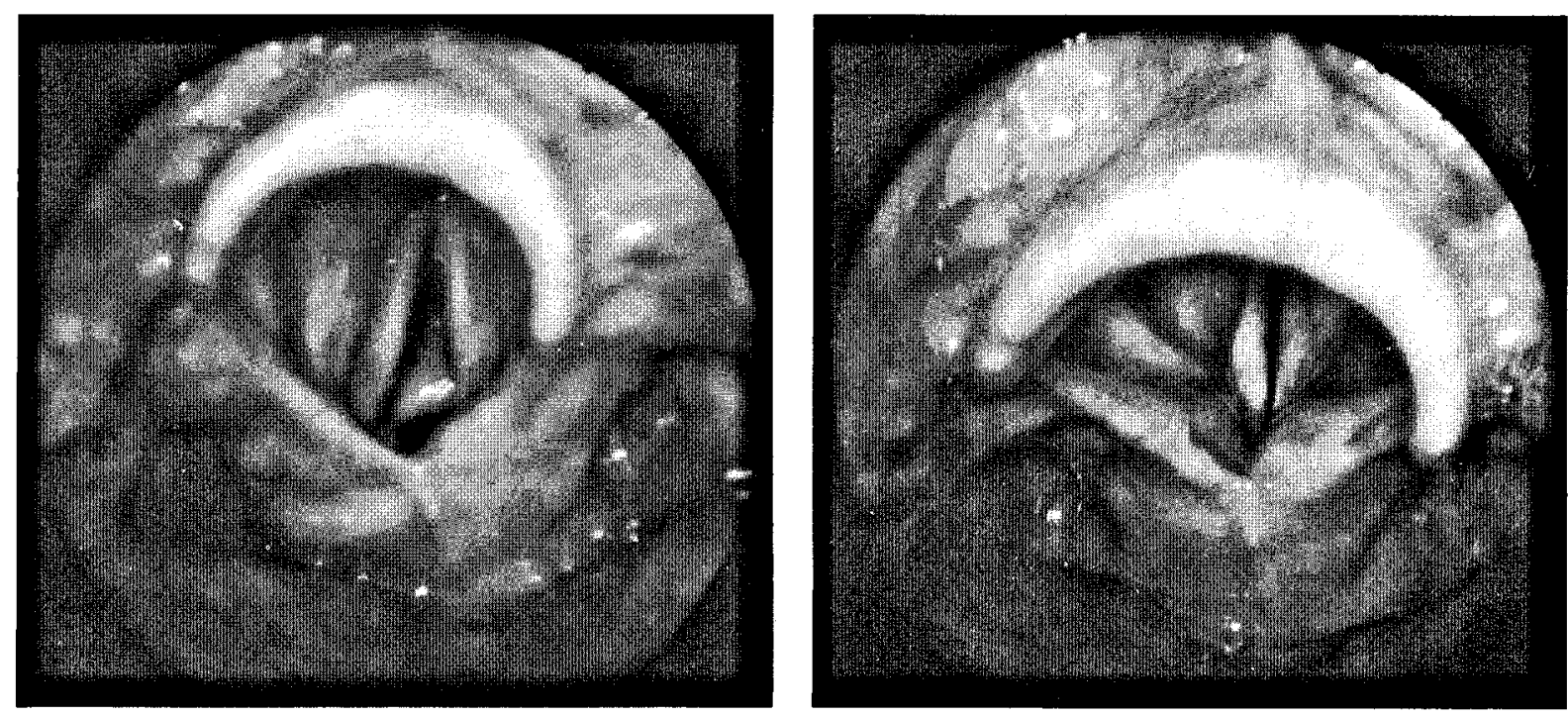

図4レーザー手術後 2 カ月目の喉頭像

$a$ : 安静呼吸時 $b$ : 発声時

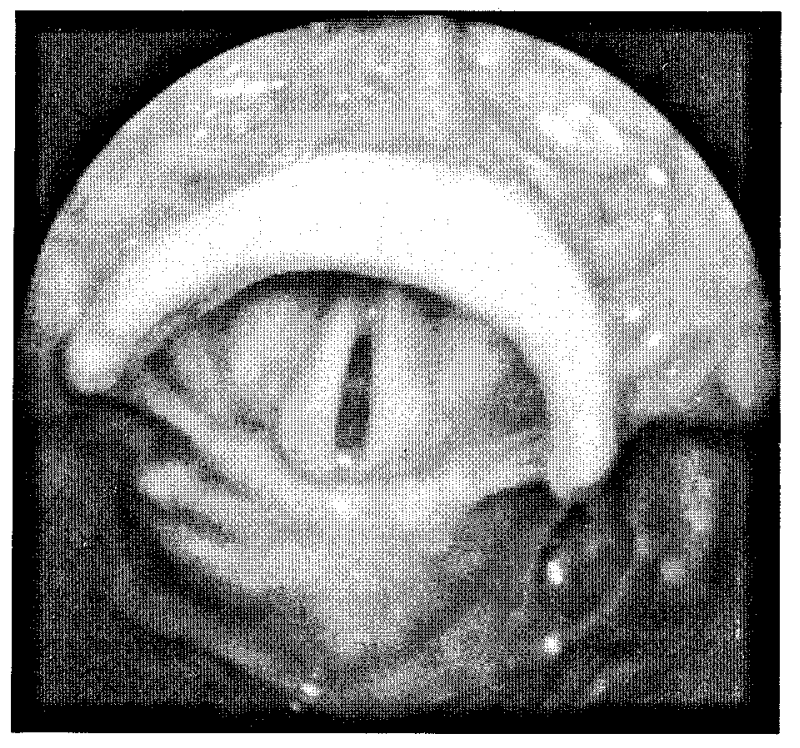

図 5 レーザー手術後 6 カ月目の喉頭像

a : 安静呼吸時

$\mathrm{b}:$ 発声時

c：気管切開孔より声門を見る。

(図の上が前交連，下が後部声門を示す)

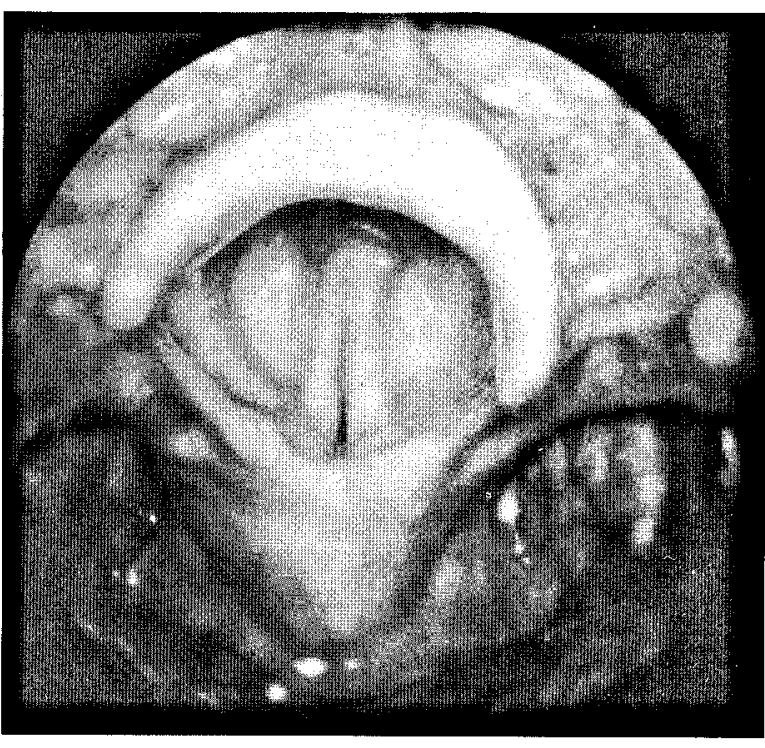

b

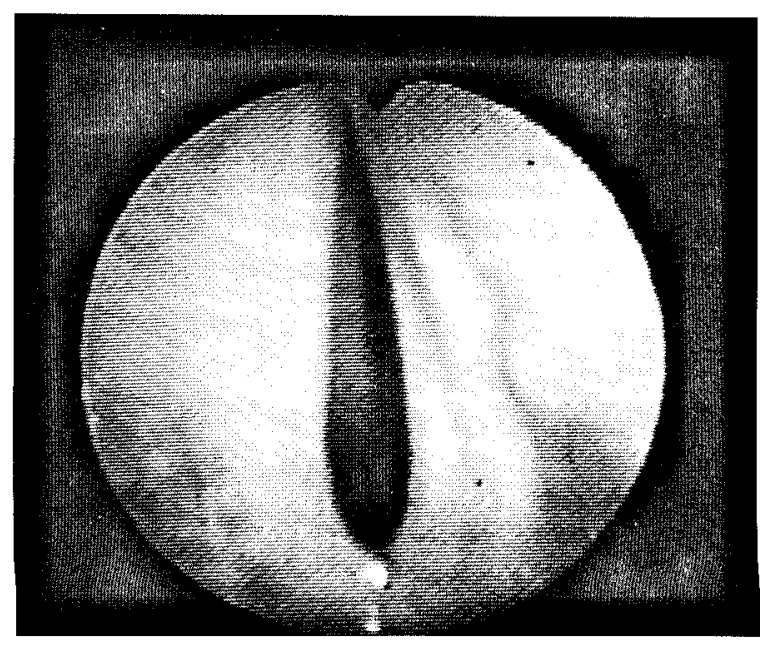




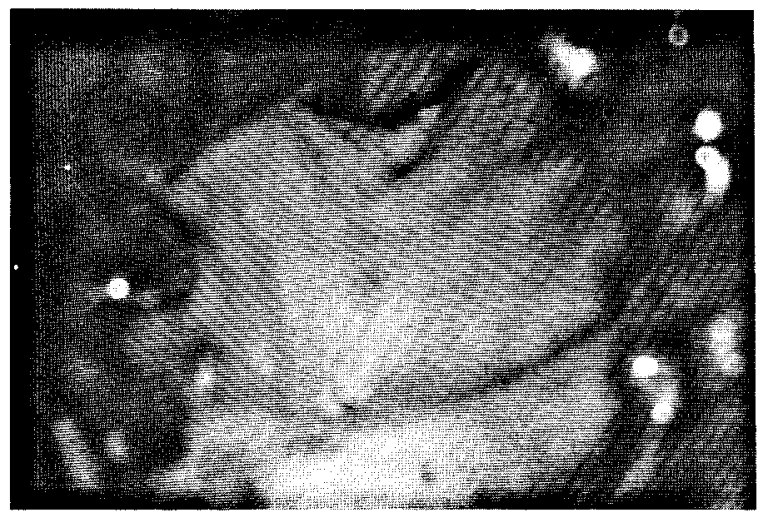

图6 喉頭截開術

甲状軟骨を正中で切開して喉頭内腔を見る

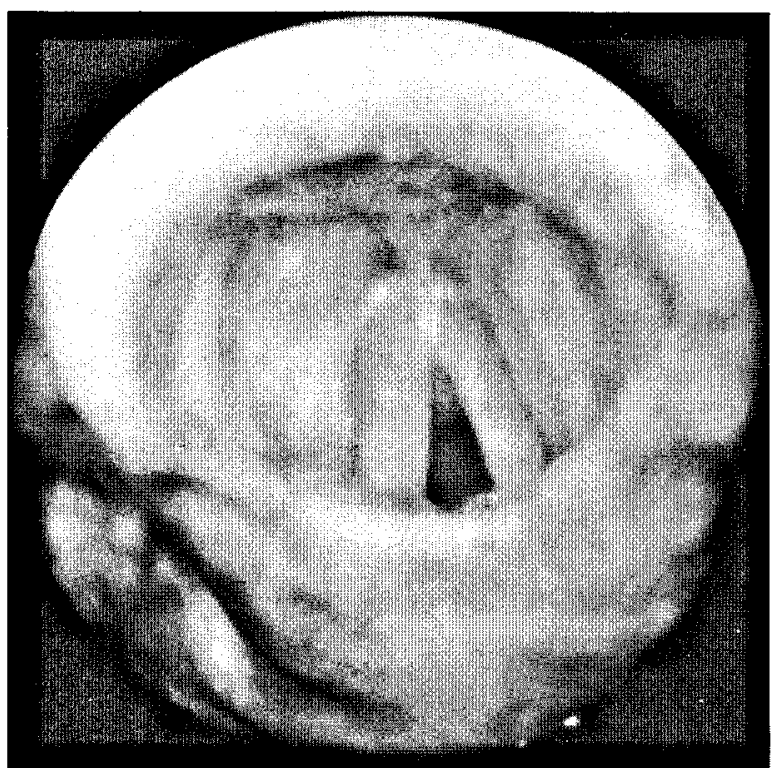

a 图 8 堠頭截開術後 2 年目の诶頭像
$\mathrm{a}:$ 安静呼吸時 $\quad \mathrm{b}:$ 発声時

図 8 侯頭截開術後 2 年目の喉頭像
$\mathrm{a}$ : 安静呼吸時 $\quad \mathrm{b}:$ 発声時

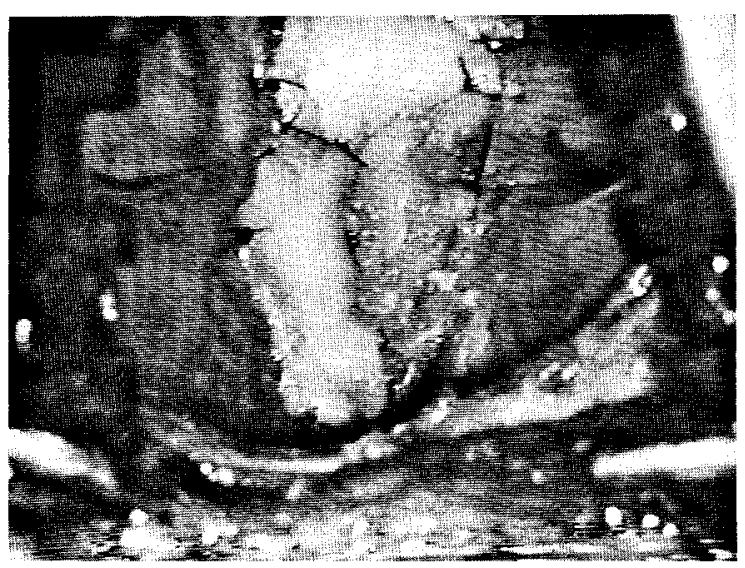

图 7 喉頭截開術 遊離粘膜并移植直後.

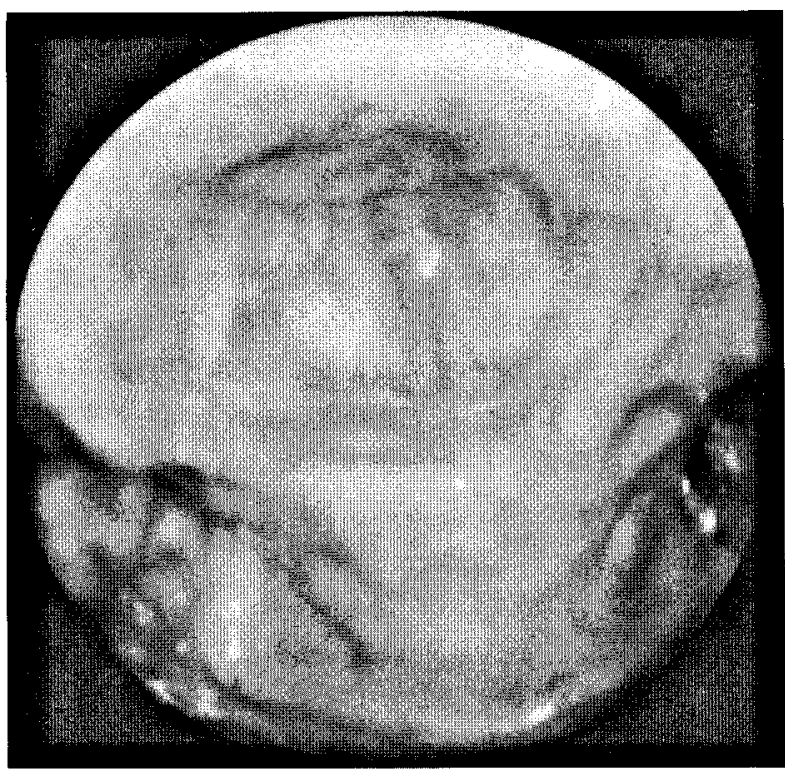

b
接着固定した（図 7). 翌日から内管を外し気管カニュー レに栓をして経喉頭的に呼吸をさせ声門の開大を促した。 2 週間後に移植粘膜は生着し, 2 力月後に声門開大もほほ 満足できるほどになり安定してきたので,10力月後に気管 切開孔を閉鎖した。 その後, 西側披裂部内側面の粘膜が痳 着し，徐々に披裂間が狭くなり披裂部の外転運動に制限が みられるようになったが, 声門幅は約 $5 \mathrm{~mm}$ 開大し安定 した (図 8).

2 年 6 カ月経過した時点での呼吸機能検查では比肺活量 $108.2 \%, 1$ 秒量 $3.281,1$ 秒率 $77.36 \%, F V$ 曲線では高肺 気量部の平低化はほとんどなく, 上気道狭窄型の障害は改 善した（図 $2-b)$ ）自覚的にも呼吸障害はない。音声は 正常で, MPT : 20sec, 発声機能検査上でも正常であった.
考按

声門狭窄の原因, 病態は種々であり，その治療法につい ては多くの報告がある，症例毎に狭窄の部位と程度を正確 に把握して, 最適な治療法を選択することが最も重要で あるリ．治療の目的は呼吸機能の改善が第一であるが, 音 声機能の保存も重視されねばならない.

1. 声門後部瘾着症の名称と分類

平野ら ${ }^{2)}$ は，声門を機能解剖学的見地から两側披裂軟骨 先端を結ぶ線を境にして前部と後部に区分し，後部声門は 呼吸道としての機能があると述べている．また，後部声門 を囲む 3 つの部位に解剖学的名称を付けて, それぞれ, 声 門後壁（ほぼ直立する壁状の構造で支持組織は輪状軟骨板 の上部), 後部声門側壁（ほぼ直立する壁状の構造で, 支 持組織は披裂軟骨内側面), 声帯軟骨部（ひだ状の構造で, 
支持組織は披裂軟骨声帯突起）と呼ぶことを提案している. 本報告では，この領域が瘕痕性に瘜着し声門が狭窄した状 態を声門後部瘜着症と仮称し, 各部位の名称はできるだけ 平野らの提唱に従った。

Hawkins $~_{3)}^{3)}$, Strong $~_{4)}^{4)}$ は狭窄の部位と程度から臨床 的分類を提唱している.両側の声帯突起間に繊維化した帯 状の癒着を形成するもの（a），両側披裂部間に粘膜下瘏 痕を形成するもの（b）の 2 型に分類している. Bogdasarianら ${ }^{5)}$ は，これらに輪状披裂関節の固着があるもの（片 側性，両側性）を加えて 4 型に分類している. 本症例は, 輪状披裂関節の固着はなく, 声帯軟骨部, 後部声門側壁, 後壁が瘏痕で瘾着した状態で（b）型に属すといえよう.

2. 治療

本疾患の手術的治療の要点は, 癒着部の切離と再瘾着防 止の対策である．手術操作には内視鏡的手術と喉頭截開術 がある。

\section{1) 内視鏡的手術}

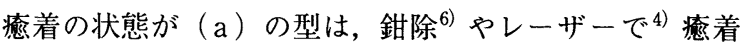
部を容易に切り離すことができて，声門は充分に開大する. Hawkins ら ${ }^{3)}$ は瘾着部を切り離した上で，全身麻酔下に 筋弛緩剤を投与して声門拡大術を施行し良い成績が得られ たと報告している。また，彼らは（b）の型にもこの方法 を用いて比較的良い結果が得られたが，披裂軟骨切除術を 必要としたものがあった. 拡大術を数回施行しても効果が なければ喉頭截開術で posterior cricoid section ${ }^{7)}$ を行 うがよいとしている．また，ステントの留置は曒痕をつく り再狭窄をおこし易いという。

レーザーによる切除は䃝痕が薄く柔らかい場合は効果的 であるが, 厚みが $1 \mathrm{~cm}$ 以上の場合や輪状披裂関節の固着 がある場合には良い結果が得られない8, 9). Duncavage ら ${ }^{9)}$ は, 再癒着防止としてステント, 拡大術, ステロイドの 局注，MTDF などの対策をとっておく必要があるとして いる. Strong $ら^{4)}$ は輪状披裂関節の固着の有無に関わら ずレーザーは有効でないとし，喉頭截開術を勧めている.

Dedo ${ }^{10)}$ は内視鏡下に瘢痕部の粘膜を切開し, 粘膜下 にレーザーで癞痕を蒸散して作製した粘膜弁（microtrapdoor flap：MTDF）で創面を覆う方法を考案した。 この方法は周囲に粘膜の余裕があること, 後方の声門幅が 3-4 mm 開いているものに適応という。この方法は, 手 術侵襲は少ないが操作には高度の技術が必要と思われる。 Langmann ら ${ }^{11)}$ はこの方法に改良を加えて, 再瘾着防止 を考慮した新しい手術手技を考案した。すなわち, 瘾着部 の粘膜を鋏切し，粘膜下の㓔痕組織を蒸散したのちに，テ フロンキールを声門に挿入し前頸部に固定するというもの である.キールの厚みは0.025インチ，長さは舌骨から輪 状軟骨まで, 幅を前交連と後交連の長さよりやや長くして 前方は前交連に沿った角度をつけて丸みをもたせたもので ある.この方法で気管切開孔を閉鎖することに成功したの は 9 例のうち 6 例で, 声門幅は平均 $3.6 \mathrm{~mm}$ まで開大した という.キールを留置している間, 特に誤嚥の問題はなく,
$3-4$ 週間後に内視鏡下にはずすことができたという。こ の方法は, 周囲に粘膜の余裕がない場合や, $1 \mathrm{~cm}$ 以上の 厚みをもつ㓔痕や，MTDFの移動のみで失敗した例にも 応用できるとした. Dedo ら ${ }^{10)}$, Langmanら ${ }^{11)} の$ 方法は, いずれも輪状披裂関節の固着したものには成功し難いという.

輪状披裂関節の固着がある場合は, 痺痕切除後, Woodman 手術 ${ }^{12)}$ ，内視鏡下レーザーによる披裂軟骨切除術 ${ }^{13)}$, レーザーで声帯側方に楔型の組織欠損をつくり, 声帯の周 囲に糸をまわして喉頭外に系を出し牽引して声帯を外転 させる方法 ${ }^{14)}$ も応用できょう。しかし，これらは呼吸困 難の改善を目的としたもので音声は犠牲にされる.

$\mathrm{T}$ チューブは Montgomery ${ }^{15)}$ の報告以来声門下狭窄に 広く使用されているものであるが, 声門後部の癒着に対し ても積極的に使用して良い結果が得られたという小児の例

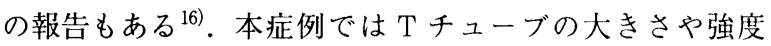
が適当でなかったという問題もあるが，誤嚥や喉頭反射の 刺激でチューブの安定が保たれなかったために装着に成功 しなかった，その結果, 前よりもさらに硬い痏痕を作り狭 窄を増強させた．再癋着防止対策として，痏痕除去後の創 部の被覆は必須であり, さらに後部声門に確実に留置固定 できるステントの改良工夫が必要である.

\section{2 ) 喉頭截開術}

posterior cricoid split ${ }^{17}$, 18) は, 甲状軟骨を正中で切開 した後に輪状軟骨後壁を痏痕とともに切開し，その部位に 自家軟骨 (甲状軟骨 ${ }^{17}$ ), 肋軟骨 ${ }^{18)}$ ) を挿入して輪状軟骨後 壁を広げる手術である. 肉芽, 瘚痕形成防止には, 筋膜・煩 部粘膜による被覆 ${ }^{17)}$, 単に移植軟骨と輪状軟骨と縫合 ${ }^{18)}$

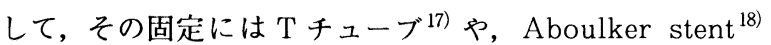
の留置が必要という.

Montgomery ${ }^{19)}$ は, 披裂間のスペースを再建する方法 として披裂間後面粘膜の有荎移植（superiorly based mucosal flap）を锥めている.これは瘾着部を切離し粘 膜下に㓔痕を除去し，さらに瘷痕化した披裂筋を切除して， 創部を前記の粘膜弁で覆い周囲粘膜に縫合するというもの である，披裂部の動きが改善しなければステントを留置し， 披裂軟骨切除術は必要ないとしている。

以上のように，喉頭截開術は後部声門の全貌を明視下に おいて，確実に癒着を切り離して粘膜下に㓔痕を除去する ことができる. と同時に再癒着防止の処置もしやすい.し かし, posterior cricoid splitは手術侵襲が大きい. 小児 の場合は, 輪状軟骨板が脆弱なものには不適当であると いう ${ }^{18)}$.

フィブリン糊は, Martin ら ${ }^{20)}$ の報告以来, 喉頭領域で も広く利用されているが, 声門後部療着症の治療において は筆者が渉猟し得た限りでは報告がない.

本症例では, 輪状軟骨に直接侵襲を加えることなく癒着 部を切離し粘膜下に瘷痕を除去した後に, 披裂部後面の粘 膜移動と口腔粘膜遊離移植で後部声門の再建と痏痕拘縮防 止を行った．披裂部はlux mucosal foldsをなすので有 茎粘膜弁を採取し易い。また, 組織欠損部の被覆には生着 
し易く採取が容易な煩部粘膜を使用した．移植部位が管腔 内であることと, 声带および披裂部の内外転運動で安定が とりにくいことを考慮して, 移植粘膜弁の縫合固定の補助 剤としてフィブリン糊を利用した。ステントの圧迫固定は 必要としなかった。声門幅は約 $5 \mathrm{~mm}$ まで開大し呼吸障 害は改善した。

一方, 後部声門を機能解剖学的にみると披裂部間には充 分な粘膜のゆとりが必要であるが, 粘膜の伸展・収縮とい う機能の再建は難しい. しかし, 音声機能を保存する後部 声門の再建にはフィブリン糊を利用した粘膜移植によりあ る程度その機能を補うことができるのではないかと考えて いる.

\section{ま と め}

声門後部療着症の一症例を報告した。喉頭マイクロレー ザー手術は，癒着部の切離や瘾痕の蒸散除去には有用であっ たが再癒着し成功しなかった。喉頭截開下に瘷痕を除去し て, 披裂部後面の粘膜移動と口腔粘膜遊離移植で後部声門 の機能再建が可能であった．移植粘膜の固定にはフィブリ ン糊が有用で, ステントの留置を必要としなかった。

本論文の要旨は第 3 回日本喉頭科学会（仙台1991年 3 月） にて発表（VTR）した。

\section{参 考 文 献}

1）村上 泰：喉頭気管狭窄。日気食会報 $41 ： 327$ 335, 1990.

2) 平野 実: 後部声門の機能解剖. 耳鼻臨床 $79: 343$ $\sim 350,1986$.

3) Hawkins DB \& Luxford WM : Laryngeal stenosis from endotracheal intubation. A review of 58 cases. Ann Otol 89:454 458, 1980.

4) Strong $\mathrm{MS}$ et al: Endoscopic management of laryngeal stenosis. Otolaryngologic Clinics of North America 12:797 805, 1979.

5) Bogdasarian RS et al : Posterior glottic laryngeal stenosis. Otolaryngol Head Neck Surg 88 : 765 772, 1980 .

6）西山明雄ほか：長期経鼻気管内挿管後に生じた声帯癒 着症. 日耳鼻 $79: 328 \sim 343,1976$.

7) Rethi A : An operation for cicatrical stenosis of the larynx. J Laryng Otol $70: 283 \sim 293,1956$.

8) Simpson GT et al : Predictive factors of success or failure in the endoscopic management of laryngeal and tracheal stenosis. Ann Otol Rhinol Laryngol $91: 384 \sim 388,1982$.

9) Duncavage JA et al: Carbon dioxide laser management of laryngeal stenosis. Ann Otol Rhinol Laryngol 94:565 569, 1985.

10) Dedo HH \& Sooy CD : Endoscopic laser repair of posterior glottic, subglottic and tracheal stenosis by division or micro-trapdoor flap. Laryngoscope $94:$ 445 450, 1984.

11) Langman $\mathrm{AW}$ et al: The endoscopic teflon keel for posterior and total glottic stenosis. Laryngoscope $99:$ 571 577, 1989.

12) Woodmann D \& Peanning CL : Bilateral abductor paralysis. Ann Otol 85:437 439, 1976.

13）小林武夫：両側声帯正中固定による呼吸困難とその 治療. 日気食会報 $41 ： 353 \sim 360,1990$.

14) Remsen $\mathrm{K}$ et al : Laser lateralization for bilateral vocal cord abductor paralysis. Otolaryngol Head Neck Surg 93: 645 649, 1985.

15) Montgomery $\mathrm{WW}:$ T-tube tracheal stent. Arch Otolaryngol $82: 320 \sim 321,1965$.

16）岩村節子ほか：声門下狭窄を伴った声門後部癄着の 2 症例. 日気食会報 $32: 223 \sim 227,1981$.

17) Montgomery WW: Chronic subglottic stenosis. Otolaryngol Clin North 17:107 113, 1984.

18) Zalzal GH : Rib cartilage grafts for the treatment of posterior glottic and subglottic stenosis in children. Ann Otol Rhinol Laryngol 97:506 $\sim 511,1988$.

19) Montgomery $W W$ : Posterior and complete laryngeal (glottic) stenosis. Arch Otolaryngol 98 : $170 \sim 175,1973$.

20) Martin F et al : Endolaryngeale Eingriffe unter verwendung Hochkonzent rierten Humanen Fibrinogens als Gewebe kleber. Weitere Erfahrungen mit dem Fibrinkleber. Laryngol Rhinol Otol 60 : 368 372,1981.

別刷請求先 $\mathbf{\mathbf { T }} 589$ 大阪府大阪狭山市大野東 $377-2$ 近畿大学医学部耳鼻咽喉科学教室 米川紘子 